\title{
Discord over IPCC meeting reopens climate dispute
}

London. Efforts to forge a scientific consensus on the need for measures to combat global warming are threatening to fall into disarray in a dispute over efforts to produce a statement on future climate change that is both scientifically sound and politically acceptable.

At the centre of the dispute is the meeting held at Maastricht in the Netherlands last month of one of three working groups of the Intergovernmental Panel on Climate Change (IPCC), the scientific body set up in 1988 by the World Meteorological Office and the United Nations Environment Programme (UNEP) to collate data on global warming and its likely implications.

The Maastricht meeting produced a 'policymakers' summary' of a special report by Working Group 1 on the impact of the carbon cycle on climate change. The summary provided new data on radiative forcing - the effect of greenhouse gases on the Earth-atmosphere energy balance that reinforce the IPCC's earlier conclusions. These formed the basis of the Climate Change Convention signed at the Earth Summit in Rio de Janeiro in 1992, on the need to reduce carbon emissions to avoid a rapid build-up of carbon dioxide in the atmosphere (see Nature 371, 274; 1994).

But the US State Department, prompted by energy-industry lobbyists, is said to be planning to send a letter to both Bert Bolin, the Swedish climatologist who is chairman of the IPCC, and Sir John Houghton, former director of Britain's Meteorological Office and chairman of the working group, expressing concern over procedures followed at the Maastricht meeting.

In particular, US officials are thought to be worried that, in apparent contravention of the IPCC's agreed procedures requiring the circulation of an underlying report at least three weeks before a meeting intended to accept it, the summary was discussed and agreed by those present in the absence of final drafts of the five individual chapters of the report (see Nature 371, 269; 1994).

The main complaint has come from the Global Climate Coalition (GCC), an industry lobby group based in Washington, which has been set up to express concern about the impact on the competitiveness of US industry of limiting carbon emissions.

The GCC's complaints are backed by a group of five scientists, including noted critics of the 'global warming' hypothesis such as Fred Seitz, former president of the National Academy of Sciences, S. Fred Singer of the University of Virginia, Henry Linden of the Illinois Institute of Technology, and Chauncey Starr, founding president of the Electric Power Institute.

Government officials involved in the IPCC defend the main substance of the working group's conclusions against the critics' charges. They point out that detailed criticisms of the impact of greenhouse gases on global warming were debated at length - and answered - both within the working group, and in the preparation of various government responses to early drafts of its conclusions.

But there is concern among IPCC officials at the possible implications of their acknowledged failure to follow approved procedures at Maastricht. They defend the procedures adopted on the grounds that the work involved in preparing the final versions of the report's chapters took longer than anticipated, and that those responsible for these final versions were present in Maastricht to answer questions about their anticipated contents.

But in its letter to Bolin and Houghton, the State Department is believed to emphasize the importance of respecting the procedures established by governments for the IPCC if its conclusions are to maintain credibility in policy-making circles.

At the Maastricht meeting, representatives of governments, industry and environmentalist groups were given an opportunity to comment on a draft of a summary of the group's scientific conclusions. IPCC officials claim this process is necessary to ensure that the report's conclusions are widely accepted. "This is not just a scientific report, but one that has to make a political impact," says one government official. "One has to get groups and governments to 'buy into' what is decided, and the only way to do this is to let them have a seat at the table."

But the process has itself caused problems with some of the scientists responsible for preparing the working group's report. "It really upset the lead authors, who felt that policy makers were making changes to the conclusions that were not based on the supporting material," says one participant.

Those who support the IPCC's main argument - that global carbon emissions must be reduced if their concentration in the atmosphere is to be stabilized at levels that prevent dangerous climate change - claim that, having failed to win the scientific debate, critics are now using the procedural error to discredit the whole IPCC process.

But they are worried that the errors could allow opponents of carbon emission controls (for example, the governments of oilproducing states such as Kuwait and Saudi Arabia) to reopen the scientific discussion when the full special report is presented to the full IPCC in Nairobi next month. (Neither Bolin nor Houghton could be reached for comment before Nature went to press.)

David Dickson

\section{Anti-plague efforts hindered by lack of recent experience}

New Delhi. The epidemic of pneumonic plague spreading through India has caught the country's scientific agencies unprepared. The government had stopped producing antiplague vaccine five years ago, and reagents and anti-sera for diagnosis of plague victims were not in stock.

India also lacked doctors who had handled plague cases and microbiologists who had seen the plague bacillus, while Khorshed Pauri, a leading virologist with the Indian Council of Medical Research (ICMR) says the present epidemics were due to failure of the surveillance system.

\section{IMAGE UNAVAILABLE FOR COPYRIGHT REASONS}

\section{Masks protect against bacillus aerosols.}

"After the last human case in 1969, we thought plague would not come back," says G.V. Satyavati, head of the ICMR. "We do not have a single plague expert in ICMR." A major consequence was that many patients were wrongly diagnosed as having the plague, and sent off to infectious diseases hospitals as a result, only to be told four days later that their plague tests were negative.

An offer from the United States to help combat the epidemic was turned down by New Delhi, which says it is confident of handling the situation on its own. Government factories are working overtime producing drugs and insecticides. Supplies of anti-plague vaccine have resumed and case diagnosis has been speeded up with the arrival of test kits from the Centers for Disease Control and Prevention in Atlanta.

Pneumonic plague has so far killed 47 in the west Indian town of Surat, where the epidemic broke out on 18 September, and four people in Delhi, India's capital. More than 1,200 people in six states are suspected to have been infected with the bacillus Yersinia pestis directly from people who fled Surat in panic.

In pneumonic plague, infection with the bacteria $Y$. pestis occurs directly through the lungs when cough-generated aerosols are inhaled from highly contagious infected individuals. This facilitates the rapid dissemination of the bacillus. Antibiotic treatment is effective but must be initiated rapidly, otherwise the disease is often fatal.

K. S. Jayaraman 